\title{
Contribution of oxidative stress to endothelial dysfunction in hypertension
}

\author{
Bruno R. Silva ${ }^{1}$, Laena Pernomian ${ }^{1}$ and Lusiane M. Bendhack ${ }^{2 *}$ \\ Department of Pharmacology, School of Medicine of Ribeirão Preto, University of São Paulo, Ribeirão Preto, São Paulo, Brazil \\ 2 Department of Physics and Chemistry, Faculty of Pharmaceutical Sciences of Ribeirão Preto, University of São Paulo, Ribeirão Preto, São Paulo, Brazil
}

\author{
Edited by: \\ Ruy R. Campos, Federal University \\ of São Paulo, Brazil \\ Reviewed by: \\ Ruy R. Campos, Federal University \\ of São Paulo, Brazil \\ Rudolf Lucas, Medical College of \\ Georgia, USA \\ *Correspondence: \\ Lusiane M. Bendhack, Faculdade de \\ Ciências Farmacêuticas de Ribeirão \\ Preto, Laboratório de Farmacologia, \\ University of São Paulo, Av. do Café \\ $s / n^{\circ}, 14040-903$ Ribeirão Preto, São \\ Paulo, Brazil. \\ e-mail:bendhack@usp.br
}

\begin{abstract}
Endothelial dysfunction is the hallmark of hypertension, which is a multifactorial disorder. In the cardiovascular system reactive oxygen species play a pivotal role in controlling the endothelial function and vascular tone. Physiologically, the endothelium-derived relaxing factors (EDRFs) and endothelium-derived contractile factors (EDCFs) that have functions on the vascular smooth muscle cells. The relaxation induced by the EDRFs nitric oxide (NO), prostacyclin, and the endothelium-derived hyperpolarization factor (EDHF) could be impaired in hypertension. The impaired ability of endothelial cells to release $\mathrm{NO}$ along with enhanced EDCFs production has been described to contribute to the endothelium dysfunction, which appears to lead to several cardiovascular diseases. The present review discusses the role of oxidative stress, vascular endothelium, and vascular tone control by EDRFs, mainly NO, and EDCFs in different models of experimental hypertension.
\end{abstract}

\begin{abstract}
Keywords: oxidative stress, endothelial dysfunction, hypertension, vascular relaxation, vascular contraction, NO
\end{abstract} availability
Hypertension is a multifactorial disorder that involves many mechanisms leading to risk factors for cardiovascular diseases. Endothelial dysfunction is defined as the imbalance between the production and bioavailability of endothelium-derived relaxing factors (EDRFs) and endothelium-derived contractile factors (EDCFs), associated with increased bioavailability of oxygen reactive species (ROS) and decreased antioxidant capacity characterized as oxidative stress. In this review we will discuss the involvement of oxidative stress and vascular endothelium as well as the importance of vascular tone control, relaxation, and contraction in hypertension.

$\mathrm{NO}$ is an important mediator released by endothelial cells. It is produced by NO synthases (NOS), which convert Larginine and molecular oxygen to L-citrulline and $\mathrm{NO}$, using such co-factors as tetrahydrobiopterin $\left(\mathrm{BH}_{4}\right)$, flavin-adeninedinucleotide, flavin-mononucleotide, and nicotinamide-adeninedinucleotide-phosphate (Thomas et al., 2008). The activity of NOS is regulated by substrate, cofactor availability, and electron transfer rate. The regulating factors such as arginine (Gornik and Creager, 2004) and $\mathrm{BH}_{4}$ (Bevers et al., 2006) can be affected by ROS that can lead to dysfunctional eNOS. As summarized in the Figure 1, in pathological states involving oxidative stress such as hypertension NOS could be uncoupled (Schulz et al., 2008). L-arginine is the substrate for both enzymes, NOS and arginase (Tousoulis et al., 2002). Zhang et al. (2004) showed that the activity of arginase in the endothelial cells of coronary arterioles is increased in hypertension, which impairs the NOmediated dilation. Similarly, as reported by Chandra et al. (2012) peroxynitrite $\left(\mathrm{ONOO}^{-}\right)$and hydrogen peroxide $\left(\mathrm{H}_{2} \mathrm{O}_{2}\right)$ increase arginase activity/expression in the endothelial cells. This should lead to NOS uncoupling with reduced NO production and augmented superoxide anion $\left(\mathrm{O}_{2}^{-}\right)$production. As shown by Romero et al. (2008), increased arginase activity in diabetes contributes to vascular endothelium dysfunction by decreasing L-arginine availability to NOS.

Endothelial dysfunction culminates in impaired endothelium-dependent relaxation due to decreased vascular NO bioavailability caused by ROS consumption. The result is $\mathrm{ONOO}^{-}$formation, lower NOS protein expression, or lack of substrate or co-factor for NOS (Crimi et al., 2007). The eNOS phosphorylation state can alter its activity; i.e., Akt-dependent phosphorylation at $\operatorname{Ser}^{1177}$ (human) or Ser ${ }^{1179}$ (bovine) activates eNOS (Fulton et al., 1999), while phosphorylation at $\mathrm{Thr}^{495}$ (human) or $\mathrm{Thr}^{497}$ (bovine) decreases its activation (Bouloumié et al., 1997). $\mathrm{H}_{2} \mathrm{O}_{2}$ initially raises eNOS Ser ${ }^{1179}$ phosphorylation and activity, in parallel with transient Akt activation (Hu et al., 2008).

In vivo measurements of $\mathrm{NO}$ and $\mathrm{H}_{2} \mathrm{O}_{2}$ in the mesenteric arteries of spontaneously hypertensive rats (SHR) revealed higher baseline $\mathrm{NO}$ and $\mathrm{H}_{2} \mathrm{O}_{2}$ concentrations than normotensive rats (Zhou et al., 2008). It is known that in resistance arteries more than in conduit vessels, EDHF is an important control of vascular tone. $\mathrm{H}_{2} \mathrm{O}_{2}$ has been shown to be a component of EDHF in several vascular beds (Meurer et al., 2005; Shimokawa, 2010; Prysyazhna et al., 2012).

Peroxynitrite can also activate eNOS by increasing basal and agonist-stimulated Ser ${ }^{1179}$ phosphorylation, although it reduces $\mathrm{NO}$ bioavailability and elevates $\mathrm{O}_{2}^{-}$production (Zou et al., 2002a). eNOS exposure to oxidants like $\mathrm{ONOO}^{-}$causes increased enzymatic uncoupling and $\mathrm{O}_{2}^{-}$generation in diabetes that contributes to endothelial cell oxidant stress (Zou et al., 2002b). Increased formation of $\mathrm{ONOO}^{-}$can inhibit prostacyclin synthase (PGIS) (Wu and Liou, 2005) and impairs $\mathrm{K}^{+}$channel activation (Gutterman et al., 2005). 

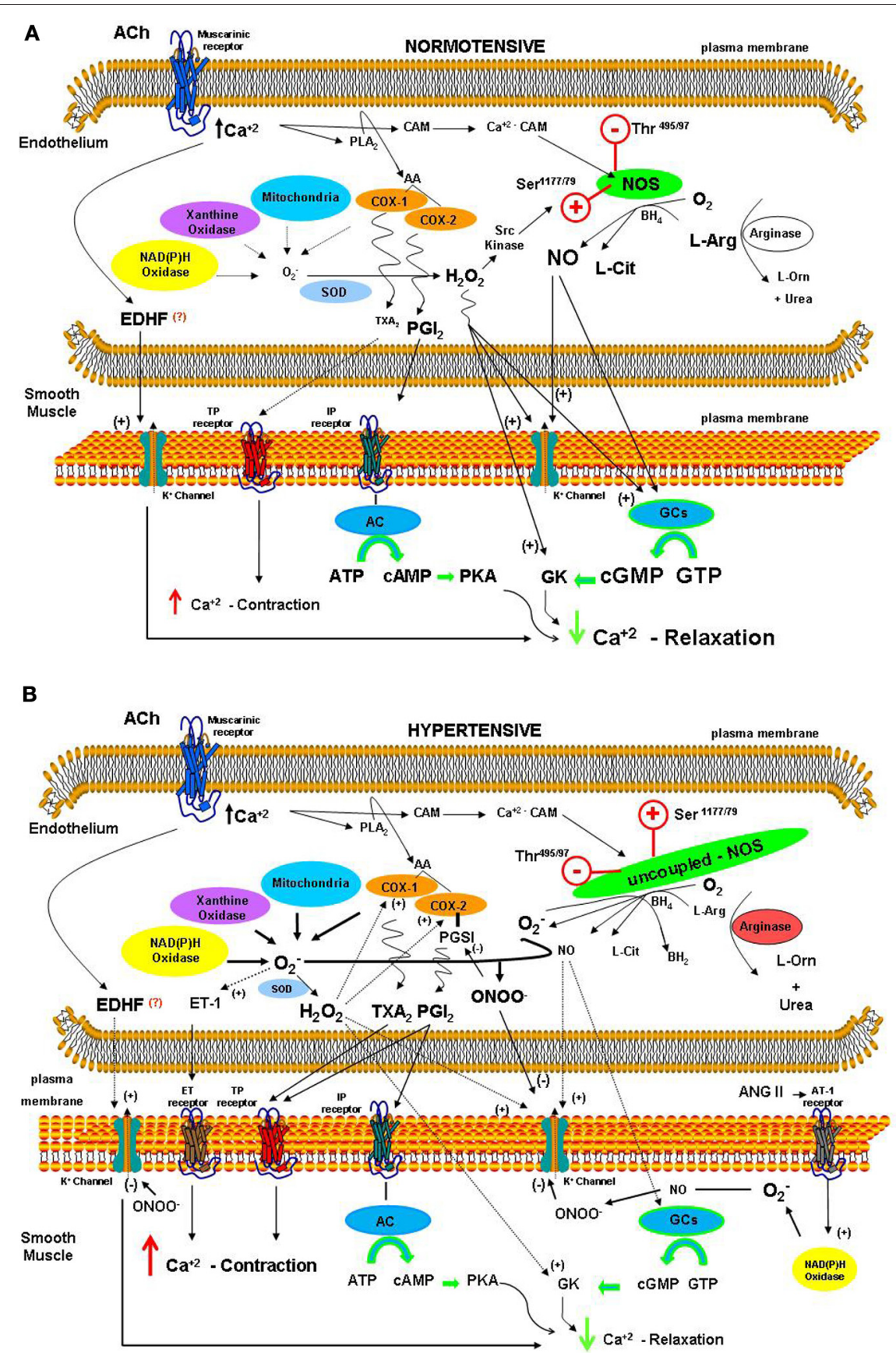

FIGURE 1 | Sources of reactive oxygen species (ROS) and proposed mechanisms for their contribution to EDRFs and EDCFs releasing involved in the control of vascular tone in isolated vessels from normotensive (A) and hypertensive (B) animals.

Increased ROS bioavailability, decreased antioxidant capacity, or both occur in many models of hypertension such as SHR (Suzuki et al., 1995), Dahl salt-sensitive (Swei et al., 1997), AngIIinfused rats (Laursen et al., 1997), renal hypertensive $2 \mathrm{~K}-1 \mathrm{C}$ (Rodrigues et al., 2008), and human hypertension (Vaziri, 2004). In endothelial cells, the ROS producers are NADPH oxidase (Rajagopalan et al., 1996), xanthine oxidase (Phan et al., 1989), uncoupled NOS (Satoh et al., 2005), cyclooxygenase (COX) (Tang et al., 2007), and mitochondria (Callera et al., 2006). The DOCAsalt model present augmented oxidative stress caused by increased $\mathrm{NADPH}$ oxidase activity, which accounts for enhanced $\mathrm{O}_{2}^{-}$production (Beswick et al., 2001). In $2 \mathrm{~K}-1 \mathrm{C}$ rats, the increased vascular $\mathrm{O}_{2}^{-}$is secondary to a protein kinase $\mathrm{C}$ ( $\mathrm{PKC}$ )-mediated activation of NADPH oxidase (Heitzer et al., 1999). However, eNOS activity is reduced by phosphorylation of the $\mathrm{Thr}^{495}$ residue in the $\mathrm{Ca}^{2+} / \mathrm{CaM}$ binding domain by PKC (Mount et al., 2007). 
Mimicking of $\mathrm{Thr}^{495}$ dephosphorylation results in eNOS uncoupling and $\mathrm{O}_{2}^{-}$production rather than $\mathrm{NO}$ generation (Lin et al., 2003). However, whether the $\mathrm{Thr}^{495}$ eNOS phosphorylation site is more phosphorylated in hypertension or contains uncoupled eNOS remains unknown.

We have investigated the vascular mechanisms involved in the vasorelaxation induced by $\mathrm{NO}$ donors that present potential capacity to replenish vascular NO upon reduced NO bioavailability. Most of the studies using NO donors are performed on endothelium-denuded arteries to avoid interference of endogenously produced NO (Bonaventura et al., 2004; Pereira et al., 2011). Impaired 2K-1C rat aorta relaxation is endotheliumdependent (Callera et al., 2004) or endothelium-independent (Bonaventura et al., 2005). Vitamin-C normalized the impaired relaxation induced by a NO donor in $2 \mathrm{~K}-1 \mathrm{C}$ rat aorta that shows the increased ROS production in the vascular smooth muscle cells (Rodrigues et al., 2008). Interestingly, the endothelium can contribute to the vasorelaxation induced by sodium nitroprusside (SNP) via NOS activation (Bonaventura et al., 2008). The endothelium negatively modulates the vasorelaxation induced by the complex (TERPY) in the rat aorta. $\mathrm{BH}_{4}$ supplementation reverses the effect of uncoupled NOS induced by TERPY (Bonaventura et al., 2009).

The altered function of endothelial cells leads to enhanced contraction (Endemann and Schiffrin, 2004). The EDCFs released under different stimuli include ET-1 (Taddei et al., 2003), some prostanoids, and ROS (Tang and Vanhoutte, 2009). ET-1 activates $\mathrm{ET}_{\mathrm{A}}$ and $\mathrm{ET}_{\mathrm{B}}$ receptors. $\mathrm{ET}_{\mathrm{A}}$ receptors are expressed on smooth muscle cells and promote contraction. $\mathrm{ET}_{\mathrm{B}}$ receptors are located on endothelial and smooth muscle cells, with opposite effects. Smooth muscle $\mathrm{ET}_{\mathrm{B}}$ activation evokes contraction, whereas endothelial $\mathrm{ET}_{\mathrm{B}}$ activation induces relaxation (Taddei et al., 2003). The imbalance in the expression of receptors or increased ET-1 production can contribute to hypertension. Hypertension associated with elevated levels of AngII leads to high vascular ET-1 production (Dohi et al., 1992) as well as ROS originated from NADPH oxidase (Touyz et al., 2002). Both factors are related to larger contractility in hypertensive rat resistance arteries.

\section{REFERENCES}

Beswick, R. A., Dorrance, A. M., and Romulo, R. C. L. (2001). $\mathrm{NADH} / \mathrm{NADPH}$ oxidase and enhanced superoxide production in the mineralocorticoid hypertensive rat. Hypertension 38, 1107-1111.

Bevers, L. M., Braam, B., Post, J. A., van Zonneveld, A. J., Rabelink, T. J., Koomans, H. A., et al. (2006). Tetrahydrobiopterin, but not Larginine, decreases NO synthase uncoupling in cells expressing high levels of endothelial NO synthase. Hypertension 47, 87-94.

Bonaventura, D., Lunardi, C. N., Rodrigues, G. J., Neto, M. A., and Bendhack, L. M. (2008). A novel mechanism of vascular relaxation induced by sodium nitroprusside in the isolated rat aorta. Nitric Oxide 18, 287-295.

Bonaventura, D., Lunardi, C. N., Rodrigues, G. J., Neto, M. A., Vercesi, J. A., de Lima, R. G., et al. (2009). Endothelium negatively modulates the vascular relaxation induced by nitric oxide donor, due to uncoupling NO synthase. J. Inorg. Biochem. 103, 1366-1374.

Bonaventura, D., Oliveira, F. S., da Silva, R. S., and Bendhack, L. M. (2005). Decreased vasodilation induced by a new nitric oxide donor in two kidney one clip hypertensive rats is due to impaired $\mathrm{K}^{+}$channel activation. Clin. Exp. Pharmacol. Physiol. 32, 478-481.

The SHR aorta exhibits a characteristic endothelial dysfunction that is not due to decreased EDRF release, but it is the result of simultaneous EDCF release. Indomethacin, a non-selective COX inhibitor, restores the blunted relaxation in SHR aorta to the level of normotensive (Lüscher and Vanhoutte, 1986), which suggests that this EDCF must be a product of the COX. Endothelium-dependent contraction is reported in the rat aorta, mesenteric and femoral arteries, and cerebral arterioles. It occurs in healthy animals, but EDCF release is exacerbated by hypertension. Selective COX-1 inhibitors abolish endothelium-dependent contraction in SHR aorta, while selective COX-2 inhibitors only display modest responses (Tang and Vanhoutte, 2009).

Endoperoxides, $\mathrm{PGI}_{2}, \mathrm{TXA}_{2}$, and ROS are proposed as COXderived EDCFs. Increased endothelial $\left[\mathrm{Ca}^{2+}\right]_{i}$ is required to evoke EDCF-mediated responses. Dysfunction in $\mathrm{Ca}^{2+}$ handling within the endothelium is important for the exacerbation of endothelium-dependent contractions in SHR aorta (Tang et al., 2007).

Independent of the genesis of hypertension, specific ROS such as $\mathrm{H}_{2} \mathrm{O}_{2}$ modify the vascular activity of NOS and COX in concentration-dependent way (Cai et al., 2003; Gil-Longo and González-Vásquez, 2005). In hypertension, ROS are involved in augmented EDCFs and diminished EDRFs release. In the L-NAME (Qu et al., 2010) and SHR (Félétou et al., 2009) models there is increased COX-derived production of contractile prostanoids. Physiologically, $\mathrm{PGI}_{2}$ evokes vasorelaxation, whereas in aging animals or SHR it induces contraction (Vanhoutte, 2011).

Inhibitors of COX (Taddei et al., 1997), NADPH oxidase (Costa et al., 2009), and xanthine oxidase (Ellis et al., 1998) or antioxidant agents such as Vitamin-C (Nishi et al., 2010) seem to diminish ROS production and EDCFs generation.

In conclusion, the data presented in this work suggest that decreased NO availability along with enhanced EDCFs production contribute to the endothelium dysfunction and impaired vascular relaxation in hypertension (Figure 1). Considering the enormous progress in the area in the last years, this work addresses the function of oxidative stress on the pathogenesis of hypertension.

Bonaventura, D., Oliveira, F. S. Togniolo, V., Tedesco, A. C., da Silva, R. S., and Bendhack, L. M. (2004). A macrocyclic nitrosyl ruthenium complex is a NO donor that induces rat aorta relaxation. Nitric Oxide 10, 83-91.

Bouloumié, A., Bauersachs, J., Linz, W., Schölkens, B. A., Wiemer, G., Fleming, I., et al. (1997). Endothelial dysfunction coincides with an enhanced nitric oxide synthase expression and superoxide anion production. Hypertension 30, 934-941.

Cai, H., Li, Z., Davis, M. E., Kanner, W., Harrison, D. G., and Dudley, S. C. Jr. (2003). Akt-dependent phosphorylation of serine $e^{1179}$ and mitogen-activated protein kinase kinase/extracellular signal-regulated kinase $1 / 2$ cooperatively mediate activation of the endothelial nitricoxide synthase by hydrogen peroxide. Mol. Pharmacol. 63, 325-331.

Callera, G. E., Tostes, R. C., Yogi, A., Montezano, A. C. I., and Touyz, R. M. (2006). Endothelin-1-induced oxidative stress in DOCA-salt hypertension involves NADPHoxidase-independent mechanisms. Clin. Sci. 110, 243-253.

Callera, G. E., Yogi, A., Tostes, R. C., Rossoni, L. V., and Bendhack, L. M. (2004). $\mathrm{Ca}^{2+}$-activated $\mathrm{K}^{+}$ channels underlying the impaired acetylcholine-induced vasodilation in $2 \mathrm{~K}-1 \mathrm{C}$ hypertensive rats. 
J. Pharmacol. Exp. Ther. 309, 1036-1042.

Chandra, S., Romero, M. J., Shatanawi, A., Alkilany, A. M., Caldwell, R. B., and Caldwell, R. W. (2012). Oxidative species increase arginase activity in endothelial cells through the RhoA/Rho kinase pathway. Br. J. Pharmacol. 165, 506-519.

Costa, C. A., Amaral, T. A. S., Carvalho, L. C., Ognibene, D. T., da Silva, A. F., Moss, M. B., et al. (2009). Antioxidant treatment with tempol and apocynin prevents endothelial dysfunction and development of renovascular hypertension. Am. J. Hypertens. 22, 1242-1249.

Crimi, E., Ignarro, L. J., and Napoli, C. (2007). Microcirculation and oxidative stress. Free Radic. Res. 41, 1364-1375.

Dohi, Y., Hahn, A. W., Boulanger, C. M., Bühler, F. R., and Lüscher, T. F. (1992). Endothelin stimulated by angiotensin II augments contractility of spontaneously hypertensive rat resistance arteries. Hypertension 19, 131-137.

Ellis, A., Li, C. G., and Rand, M. J. (1998). Effect of xanthine oxidase inhibition on endotheliumdependent and nitrergic relaxations. Eur. J. Pharmacol. 356, 41-47.

Endemann, D. H., and Schiffrin, E. L. (2004). Endothelial dysfunction. J. Am. Soc. Nephrol. 15, 1983-1992.

Félétou, M., Verbeuren, T. J., and Vanhoutte, P. M. (2009). Endothelium-dependent contractions in SHR: a tale of prostanoid TP and IP receptors. Br. J. Pharmacol. 156, 563-574.

Fulton, D., Gratton, J., McCabe, T. J., Fontana, J., Fujio, Y., Walsh, K., et al. (1999). Regulation of endotheliumderived nitric oxide production by the protein kinase Akt. Nature 399, 597-601.

Gil-Longo, J., and González-Vásquez, C. (2005). Characterization of four different effects elicited by $\mathrm{H}_{2} \mathrm{O}_{2}$ in rat aorta. Vasc. Pharmacol. 43, 128-138.

Gornik, H. L., and Creager, M. A. (2004). Arginine and endothelial and vascular healthy. J. Nutr. 134, 2880S-2887S.

Gutterman, D. D., Miura, H., and Liu, Y. (2005). Redox modulation of vascular tone: focus of potassium channel mechanisms of dilation. Arterioscler. Thromb. Vasc. Biol. 25, 671-678.

Heitzer, T., Wenzel, U., Hink, U., Krollner, D., Skatchkov, M., Stahl, R. A., et al. (1999). Increased $\mathrm{NAD}(\mathrm{P}) \mathrm{H} \quad$ oxidase-mediated superoxide production in
Renovascular hypertension: evidence for an involvement of protein kinase C. Kidney Int. 55, 252-260.

Hu, Z., Chen, J., Wei, Q., and Xia, Y. (2008). Bidirectional actions of hydrogen peroxide on endothelial nitric-oxide synthase phosphorylation and function - co-commitment and interplay of Akt and AMPK. J. Biol. Chem. 283, 25256-25263.

Laursen, J. B., Rajagopalan, S., Galis, Z., Tarpey, M., Freeman, B. A., and Harrison, D. G. (1997). Role of superoxide in angiotensin IIinduced but not catecholamineinduced hypertension. Circulation 95, 588-593.

Lin, M. I., Fulton, D., Babbitt, R., Fleming, I., Busse, R., Pritchard, K. A. Jr., et al. (2003). Phosphorylation of threonine ${ }^{497}$ in endothelial nitric-oxide synthase coordinates the coupling of $\mathrm{L}$-arginine metabolism to efficient nitric oxide production. J. Biol. Chem. 278, 44719-44726.

Lüscher, T. F., and Vanhoutte, P. M. (1986). Endothelium-dependent contractions to acetylcholine in the aorta of the spontaneously hypertensive rat. Hypertension 8, 344-348.

Meurer, S., Pioch, S., Gross, S., and Müller-Esterl, W. (2005). Reactive oxygen species induce tyrosine phosphorylation of and Src kinase recruitment to NO-sensitive guanylyl cyclase. J. Biol. Chem. 280, 33149-33156.

Mount, P. F., Kemp, B. E., and Power, D. A. (2007). Regulation of endothelial and myocardial NO synthesis by multi-site eNOS phosphorylation. J. Mol. Cell. Cardiol. 42, 271-279.

Nishi, E. E., Oliveira-Sales, E. B., Bergamashi, C. T., Oliveira, T. G. C., Boim, M. A., and Campos, R. R. (2010). Chronic antioxidant treatment improves arterial renovascular hypertension and oxidative stress markers in the kidney in Wistar rats. Am. J. Hypertens. 23, 473-480.

Pereira, A. C., Ford, P. C., da Silva, R. S., and Bendhack, L. M. (2011). Ruthenium-nitrite complex as pro-drug releases NO in a tissue and enzyme-dependent way. Nitric Oxide 24, 192-198.

Phan, S. H., Gannon, D. E., Varani, J., Ryan, U. S., and Ward, P. A. (1989). Xanthine oxidase activity in rat pulmonary artery endothelial cells and its alteration by activated neutrophils. Am. J. Pathol. 134, 1201-1211.

Prysyazhna, O., Rudyk, O., and Eaton, P. (2012). Single atom substitution in mouse protein kinase $\mathrm{G}$ eliminates oxidant sensing to cause hypertension. Nat. Med. 18, 286-290.

Qu, C., Leung, S. W. S., Vanhoutte, P. M., and Man, R. Y. K. (2010) Chronic inhibition of nitric-oxide synthase potentiates endotheliumdependent contractions in the rat aorta by augmenting the expression of cyclooxygenase-2. J. Pharmacol. Exp. Ther. 334, 373-380.

Rajagopalan, S., Kurz, S., Münzel, T., Tarpey, M., Freeman, B. A., Griendling, K. K., et al. (1996) Angiotensin II mediated hypertension in the rat increases vascular superoxide production via membrane NADH/NADPH oxidase activation: contribution to alterations of vasomotor tone. J. Clin. Invest. 97, 1916-1923.

Rodrigues, G. J., Lunardi, C. N., Lima, R. G., Santos, C. X., Laurindo, F. R. M., da Silva, R. S., et al. (2008). Vitamin C improves the effect of a new nitric oxide donor on the vascular smooth muscle from renal hypertensive rats. Nitric Oxide 18, 176-183.

Romero, M. J., Platt, D. H., Tawfik, H. E., Labazi, M., El-Remessy, A. B. Bartoli, M., et al. (2008). Diabetesinduced coronary vascular dysfunction involves increased arginase activity. Circ. Res. 102, 95-102.

Satoh, M., Fujimoto, S., Haruna, Y., Arakawa, S., Horike, H., Komai, N., et al. (2005). NAD (P)H oxidase and uncoupled nitric oxide synthase are major sources of glomerular superoxide in rats with experimental diabetic nephropathy. Am. J. Physiol 288, F1144-F1152.

Schulz, E., Jansen, T., Wenzel, P., Daiber, A., and Münzel, T. (2008) Nitric oxide, tetrahydrobiopterin, oxidative stress and endothelial dysfunction in hypertension. Antioxid. Redox Signal. 10, 1115-1126.

Shimokawa, H. (2010). Hydrogen peroxide as an endothelium-derived hyperpolarizing factor. Pflugers Arch. 459, 915-922.

Suzuki, H., Swei, A., Zweifach, B. W., and Schmid-Schönbein, G. W. (1995). In vivo evidence for microvascular oxidative stress in spontaneously hypertensive rats. hydroethidine microfluorography. Hypertension 25, 1083-1089.

Swei, A., Lacy, F., DeLano, F. A., and Schmid-Schönbein, G. W. (1997). Oxidative stress in the Dahl hypertensive rat. Hypertension 30, 1628-1633.

Taddei, S., Ghiadoni, L., Virdis, A., Versari, D., and Salvetti, A. (2003). Mechanisms of endothelial dysfunction: clinical significance and preventive non-pharmacological therapeutic strategies. Curr. Pharm. Des. 9, 2385-2402.

Taddei, S., Virdis, A., Ghiadoni, L. Magagna, A., and Salvetti, A. (1997). Cyclooxygenase inhibition restores nitric oxide activity in essential hypertension. Hypertension 29, S274-S279.

Tang, E. H., Leung, F. P., Huang, Y., Félétou, M., Man, R. Y., and Vanhoutte, P. M. (2007). Calcium and reactive oxygen species increase in endothelial cells in response to releasers of endothelium-derived contracting factor. Br. J. Pharmacol. 151, 15-23.

Tang, E. H. C., and Vanhoutte, P. M. (2009). Prostanoid and reactive oxygen species: team players in endothelium-dependent contractions. Pharmacol. Ther. 122, 140-149.

Thomas, D. D., Ridnour, L. A., Isenberg, J. S., Flores-Santana, W. Switzer, C. H., Donzelli, S., et al. (2008). The chemical biology of nitric oxide: implications in cellular signaling. Free Radic. Biol. Med. 45, 18-31.

Tousoulis, D., Antoniades, C. Tentolouris, C., Goumas, G., Stefanadis, C., and Toutouzas, P. (2002). L-arginine in cardiovascular disease: dream or reality? Vasc. Med. 7, 203-211.

Touyz, R. M., Chen, X., Tabet, F., Yao, G., He, G., Quinn, M. T., et al. (2002). Expression of a functionally active $\mathrm{gp}_{91 p h o x}$-containing neutrophil-type $\mathrm{NAD}(\mathrm{P}) \mathrm{H}$ oxidase in smooth muscle cells from human resistance arteries: regulation by angiotensin II. Circ. Res. 90, 1205-1213.

Vanhoutte, P. M. (2011). Endotheliumdependent contractions in hypertension: when prostacyclin becomes ugly. Hypertension 57, 526-531.

Vaziri, N. D. (2004). Roles of oxidative stress and antioxidant therapy in chronic kidney disease and hypertension. Curr. Opin. Nephrol. Hypertens. 13, 93-99.

Wu, K. K., and Liou, J. (2005). Cellular and molecular biology of prostacyclin synthase. Biochem. Biophys. Res. Commun. 338, 45-52.

Zhang, C., Hein, T. W., Wang, W., Miller, M. W., Fossum, T. W., McDonald, M. M., et al. (2004). Upregulation of vascular arginase in hypertension decreases nitric oxidemediated dilation of coronary arterioles. Hypertension 44, 935-943.

Zhou, X., Bohlen, H. G., Miller, S. J., and Unthank, J. L. (2008). 
$\mathrm{NAD}(\mathrm{P}) \mathrm{H}$ oxidase-derived peroxide mediates elevated basal and impaired flow-induced $\mathrm{NO}$ production in SHR mesenteric arteries in vivo. Am. J. Physiol. 295, H1008-H1016.

Zou, M. H., Hou, X. Y., Shi, C. M., Nagata, D., Walsh, K., and Cohen, R. A. (2002a). Modulation by peroxynitrite of Akt- and AMPactivated kinase-dependent Ser ${ }^{1179}$ phosphorylation of endothelial nitric oxide synthase. J. Biol. Chem. 36, 32552-32557.

Zou, M. H., Shi, C., and Cohen, R. A. (2002b). Oxidation of the zincthiolate complex and uncoupling of endothelial nitric oxide synthase by peroxynitrite. J. Clin. Invest. 109, 817-826.

Conflict of Interest Statement: The authors declare that the research was conducted in the absence of any commercial or financial relationships that could be construed as a potential conflict of interest.

Received: 03 August 2012; accepted: 05 November 2012; published online: 05 December 2012.

Citation: Silva BR, Pernomian L and Bendhack LM (2012) Contribution of oxidative stress to endothelial dysfunction in hypertension. Front. Physio. 3:441. doi: 10.3389/fphys.2012.00441
This article was submitted to Frontiers in Oxidant Physiology, a specialty of Frontiers in Physiology.

Copyright (c) 2012 Silva, Pernomian and Bendhack. This is an open-access article distributed under the terms of the Creative Commons Attribution License, which permits use, distribution and reproduction in other forums, provided the original authors and source are credited and subject to any copyright notices concerning any third-party graphics etc. 